UDK 631.15:331.102.344

DOI: 10.18524/2413-9998/2018.2(39).144911

\author{
V. I. Borshch, \\ $\mathrm{PhD}$ in Economics, \\ associate professor \\ of Department of management and economics \\ of Odessa I. I. Mechnikov National University \\ 24/26 Frantsuzkyi bulvar, Odessa, 65058, Ukraine, \\ e-mail: viktoriyaborshch@gmail.com
}

\author{
V. O. Chabanenko, \\ magister of $2^{\text {nd }}$ course \\ of Odessa I. I. Mechnikov National University \\ 24/26 Frantsuzkyi bulvar, Odessa, 65058, Ukraine
}

\title{
IMPLEMENTATION OF THE INTELLECTUAL TECHNOLOGIES INTO THE MANAGEMENT SYSTEM OF THE MODERN ENTERPRISE: THEORETICAL BASIS
}

The issues of implementation of the intellectual technologies into the management system of the modern enterprise are investigated in this article. Intellectualization is viewed as the main background for this process. In the article authors examine different types and directions of the intellectualization process (intellectualization of the society, of the economy and of the labour activity). And we see that these directions have different results of their activity. The impact of the intellectualization of the society is viewed at the macro level and influence living conditions, societies' development and so on. The impact of the economy intellectualization is viewed at the meso level, that means the economic and productive development of the scope of some branches. And the impact of the labour activity intellectualization is viewed at the micro level, when it influence certain branch, enterprise or even personnel of the company.

In the article the factors of influence on the intellectualization process are viewed. Among them we can highlight next factors: labour, scientific, educational, managerial, socio-cultural, informational and communicational. They create the background for the effective realization of the intellectualization process.

Also it is analyzed the concept of intellectual technologies. The authors adhere to the classification, in which three types of intellectual technologies are proposed. They are operational technologies, industrial internet technologies and informational technologies. The main advantages of the implementation of intellectual technologies into the business practice are overviewed.

Thus, we can approve that the implementation of the intellectual technologies creates the new quality of the business activity, has the great impact on the state and its population.

Key words: intellectual technology, intellectualization, management system. 
The modern stage of development of Ukrainian and world society is characterized by the strengthening of the knowledge's and intelligence's role in the economic and entrepreneurial activity. Today, intellectual abilities and human knowledge are the catalyst for the large-scale institutional changes and the continuous innovation development of the country.

Intellectualization processes have extended all the spheres of the human activities at the modern stage of the societies' development. Intellectualization is the complex, multidimensional and multifactorial process.

The problem of the intellectual technologies' use is rather new for Ukrainian management science, because our country has not still achieved such level of the innovation development and implementation into all activities of the enterprise, as highly developed countries, for example USA, Japan, Germany, and even as developing countries, as India and China. Today this problem is researched by such domestic scientists as A. Antkhov, O. Melnyk, A. Kuzmin, A. Turylo, N. Hryhorak. But nevertheless, these scientists explore this issue in the general (as the problem of the intellectualization of economic or entrepreneurial activity) or from the perspective of the specific economic branch (e.g., implementation into the productive sphere of agriculture, logistics, so on). Yes, the implementation of some intellectual technologies in the management system of Ukrainian enterprises is conducted, but often it has spontaneous character and is based on own will of the enterprise's holder. Thus, the scientific researches of these issues from the point of view of the scientific background are urgent.

The main goal of this article is to analyze the scientific background of the intellectual technologies implementation into the management system of the enterprise.

Implementation of the intellectual technologies is based on the intellectualization process.

As it was above mentioned, intellectualization is the complex process, which mainly has the following directions:

1) intellectualization of the human personal characteristics, that consists in continuous education, development, building new skills and abilities; mental development and formation of critical thinking and so on;

2) general intellectualization, that means informational and computer equipping, provision of the newest intellectual technologies to the production, enterprise and national economy, generally;

3) development of the intellectual and informational space on the basis of the Internet technologies and mobile services of the new generation, their constant development and improvement, that results in the changes of the 
forms of the economic and financial activity, enterprises' types, character of their interaction in the external and internal environment and so on;

4) general robotization and creation of the artificial intelligence and its implementation into the productive and organizational activity of the enterprise.

From the point of view of economy, intellectualization at the macro level covers intellectual markets, markets of innovations, capital, technologies, and knowledge, so on, that results formation of the economy of the new type - postindustrial one. At the micro level, we mean by the intellectualization process intellectual, human and innovation capitals, intellectual and informational technologies as the main factors of the enterprise's competitiveness at the market.

If we view the intellectualization from the position of entrepreneurship, then the intellectual product is the main economic product (e.g., know-how, technology, patent and so on) and hi-tech product, in which the share of expenditures on $R \& D$ is about 3,5 \% [2, p. 17].

Another authors, A. A. Antokhonov [1, p. 31-32] and O. L. Melnyk [3] for example, allocate the following directions of the intellectualization in the context of the economic theory:

1) intellectualization of the society, that means enhancing the role of the results of the use of the individual's intellectual abilities for the societies' development, improvement of the living conditions and the further progress stimulation;

2) intellectualization of the economy, that means enhancing the role of the results of the use of the individual's intellectual abilities for the economic development, optimization of expending resources relatively the received income;

3) intellectualization of the labour activity, which characterizes the socio-economic trend and leads to changing conditions, features, labour tools, means and its subject. The expansion of the innovative intellectual thinking takes place due to the step-by-step production satiety with the knowledge-intensive technologies and innovations.

So, we can give the following definition of the intellectualization. It is the intellectual tool of the economic development, based on the knowledge and ensures the competitiveness of the economic entities through the growth of the organizational intellect and use of the different types of the capital. Intellectualization at the enterprise characterizes the abilities of its leader, the quality of the intellectual activity of the enterprise's personnel, the availability of the intellectual capital, the ability to receive intellectual rent and so on. 
The main elements of the intellectualization are:

- information and informational technologies;

- $\quad$ scientific knowledge;

- professional, scientific and cultural potential of the person and society;

- innovation capital and technologies;

- intellectual capital and technologies.

Factors, influencing the intellectualization process, are the following:

1) labour sphere, i.e. the environment of the use of the population's social and labour potential;

2) scientific and educational sphere, i.e. the field of the education and continuous development of the social and labour potential of the population;

3) management sphere, i.e. the hierarchy of the authorities' structure with all its influence factors at the processes of the societies' development and the ability to realize its intellectual potential;

4) socio-cultural sphere, i.e. the field of the development of the elements of the social infrastructure, that meet the requirements of the qualitative characteristics of the population's life and let to create the comfortable conditions for the human intellectual abilities realization;

5) informational and communicational sphere, i.e. a network of the virtual relationships among the economic entities, allowing to share information and knowledge, to develop intellectual abilities and the skill to use them [1, p. 30].

Thus, we see that the system of the factors of influence is very complicated and many spheres have an impact on the intellectualization process course.

So, what must be done at the state, regional levels and the level of the company to ensure the intellectualization process? In our view, the following efforts must be undertaken:

1. At the state level the conditions for the realization of the human intellectual abilities must be created through the development of the knowledge inclusive types of economic activity, engagement of the creative, talented youth, creation of the innovative workplaces;

2. Ensuring of the transformation of the intellectual potential to the capital through the market gears and maximum involvement of the inner resources;

3. Creation of the demand for the specialists and employees with the appropriate intellectual abilities;

4. Promotion of the competition in the employment sphere by means of the support of the management intellectualization through the financial resources use; 
5. Implementation of the concept of the social responsible business;

6. Support of the creation of the digital economic space with the new virtual forms of business, which requires specialists with the high intellectual abilities;

7. Implementation of the intellectual technologies in the different spheres of activity.

The measures provided above must be ensured by the market mechanism of reallocation of the human resources and human capital among those types of the economic activity, that provide sustenance of this type of economic branch. So, these measures will provide the creation of the new workplaces, new economic branches and market segments at the state level. It means that intellectualization process displays the highest level of resultiveness under the condition of the social utility of the results of the intellectual activity.

Intellectual technology is the man result of the intellectualization process.

In general terms, intellectual technologies are defined as the systems, in which data are being generated, analyzed, interpreted and used. They relate to the analysis of data and the development of solutions directly in the system in which the relevant data is generated.

There are three main types of intellectual technologies:

- operational technology (OT);

- industrial Internet technology (IToT);

- information technology (IT) [5].

Operating technologies are commonly used at the manufacturing enterprises. Information technologies are common at the telecommunication and media industries. IToT is a combination of operational and information technology, it is used at different branches and fields of activity and is very popular in the modern business environment. A prime example of its use is their use at power stations. Sensors for information reading are connected with turbines, and due to this the physical and statistical data about their work, temperature, humidity, vibration, the state of physical wear of the machine, power, etc. is received. Forecast analytics programs process the resulting data and provide an immediate overview of the state of the equipment, its performance, and other benchmarks. This makes it possible to better control the maintenance of equipment, predict physical wear, malfunction, performance, etc. Thus, the information gained through the IToT makes it possible to create a significant commercial value for the enterprise $[4 ; 5]$.

Hence, intellectual technologies are part of the analytical, operational and strategic management of the enterprise. If we consider them as an integral 
part of analytical management, then we can state that they are "electronic interface", i. e. a program, in which control and analysis are carried out on the main indicators of the enterprise by its various structural divisions. If we consider intellectual technologies as an integral part of operational management, then due to them it can be ensured the production process, its control, etc. If we consider intellectual technologies as an integral part of strategic management, then the results of the analysis become the basis for making strategic decisions on the whole for the company and its structural divisions.

The main advantages of using intellectual technologies in the enterprise management system are the following:

1) increasing business efficiency by the improvement of the resultiveness of the business processes through their automatization and ensuring compliance with the requirements of specific business, industry, activity specifics, corporate rules and standards;

2) increasing the profitability of the enterprise due to introduction of constant automatic analysis of its activity;

3 ) the risk of "leakage of information" decreases due to the refusal of the enterprise to attract third-party organizations;

4) reducing costs in the long run, owing to the refusal of the outsourcing of the analysis function despite the significant previous costs of the purchase and introduction into the enterprise's activity;

5) the possibility of autonomous operation due to the refusal of the "work of the network", which at any moment may fail;

6) reducing the delay in the process of "receiving information - processing information - decision-making";

7) increasing of "bandwidth" for reception and processing of data due to the cloud technologies and creation of data bank of the enterprise.

Most of the intellectual technologies are based on the continuous interaction of equipment, people and the environment, providing a new level of quality. Thus their implementation into the management system of the enterprise create are new quality of its realization and becomes a background for formation of the managerial capital of the enterprise.

\section{References}

1. Antokhov, A. A. (2016). Rehionalna ekonomika ta intelektualizatsiia suspilstva: innovatsiini aspektu vzaiemorozvyktu. Monohrafia [Regional economics and societies' intellectualization: innovative aspects of their development]. Lviv : PP "Vydavnytstvo "BONA". [in Ukrainian]. 
2. Akhtiamov, M. K., Kuznetsova, N. A. \& Saakova, L. V. (2011). Intellektualizatisiia predprinimatelstva kak obektivnaia zakonomernost razvitiia ekonomiki znanii [Intellectualization of the entrepreneurship as the objective pattern of the knowledge economy development]. Rossiiskoe predprinimatelstvo. - Russian entrepreneurship, № 4 (2), pp. 16-20. [in Russian].

3. Melnyk, O. L. (2007). Informatsiine suspilstvo ta suspilstvo znan stanovlennia ta rozvytok poniat [Informational society and knowledge society - formation and development of the definitions]. Visnyk natsionalnoho technichnoho universytetu Ukrainy "Kyivskyi politechnichnyi instytut". Filosofiia. Psycholohiia. Pedahohika. - Herald of the national technical university of Ukraine "Kyiv polytechnic institute". Philosophy. Psychology. Pedagogy, № 2, Issue 2. Retrieved from http://novyn.kpi.ua/2007-2-2/12 Melnik.pdf [in Ukrainian].

4. Bradicich, T. (2017). The Intelligent Edge: What it is, what it's not, and why it's useful. Retrieved from https://www.hpe.com/us/en/insights/articles/theintelligent-edge-what-it-is-what-its-not-and-why-its-useful-1704.html

5. Hewlett Packard Enterprise. Intellektualnye technologii. [Hewlett Packard Enterprise. Intellectual technologies]. Retrieved from https://www.hpe.com/ ru/ru/what-is/intelligent-edge.html\# [in Russian].

Стаття надійшла 10.08.2018 p.

\section{В. И. Борщ,}

кандидат экономических наук, доцент кафедры менеджмента и инноваций, Одесский национальный университет имени И. И. Мечникова, Французский бульвар, 24/26, м. Одеса, 65058, Украина, e-mail: viktoriyaborshch@gmail.com

\section{В. О. Чабаненко,} магистр 2 курса Одесский национальный университет имени И. И. Мечникова, Французский бульвар, 24/26, м. Одеса, 65058, Украина

\section{ТЕОРЕТИЧЕСКИЕ ОСНОВЫ ВНЕДРЕНИЯ ИНТЕЛЛЕКТУАЛЬНЫХ ТЕХНОЛОГИЙ В СИСТЕМУ УПРАВЛЕНИЯ СОВРЕМЕННЫМ ПРЕДПРИЯТИЕМ}

В статье рассматриваются проблемы интеллектуализации экономики, общества и предпринимательства. Также анализируется проблематика внедрения интеллектуальных технологий в систему управления предприятия. Интеллектуальные технологии, по мнению авторов, являются результатом процесса интеллектуализации. 
В статье рассмотрены основные направления интеллектуализации, такие как интеллектуализация общества, экономики и трудовой деятельности. Проанализировано влияние процесса интеллектуализации на микро, мезо и макро уровнях. Изучены факторы, влияющие на протекание процесса интеллектуализации.

Основное внимание уделено рассмотрению понятия «интеллектуальные технологии», их классификации и влиянию на организационный, производственный, управленческий и иные бизнес-процессы предприятия.

Ключевые слова: интеллектуальная технология, интеллектуализация, система управления.

\author{
В. І. Борщ, \\ кандидат економічних наук, \\ доцент кафедри менеджменту та інновацій, \\ Одеський національний університет імені I. I. Мечникова, \\ Французький бульвар, 24/26, м. Одеса, 65058, Україна, \\ e-mail: viktoriyaborshch@gmail.com

\section{В. О. Чабаненко,} \\ магістр 2 курсу \\ Одеського національного університету імені I. I. Мечникова \\ Французький бульвар, 24/26, м. Одеса, 65058, Україна
}

\title{
ТЕОРЕТИЧНІ ЗАСАДИ ВПРОВАДЖЕННЯ ІНТЕЛЕКТУАЛЬНИХ ТЕХНОЛОГІЙ В СИСТЕМУ УПРАВЛІННЯ СУЧАСНИМ ПІДПРИЕМСТВОМ
}

У статті розглядаються проблеми інтелектуалізації економіки, суспільства і підприємництва. Також аналізується проблематика впровадження інтелектуальних технологій в систему управління підприємством. Інтелектуальні технології, на думку авторів, є результатом процесу інтелектуалізації.

У статті розглянуті основні напрямки інтелектуалізації, такі як інтелектуалізація суспільства, економіки та трудової діяльності. Проаналізовано вплив процесу інтелектуалізації на мікро, мезо і макро рівнях. Вивчено фактори, що впливають на перебіг процесу інтелектуалізації.

Основну увагу приділено розгляду поняття «інтелектуальні технології», їх класифікації та впливу на організаційний, виробничий, управлінський і інші бізнес-процеси підприємства. управління.

Ключові слова: інтелектуальна технологія, інтелектуалізація, система 


\section{Список використаної літератури}

1. Антохов А. А. Регіональна економіка та інтелектуалізація суспільства: інноваційні аспекти взаєморозвитку. Монографія / А. А. Антохов. Львів : ПП «Видавництво «БОНА», 2016. - 420 с.

2. Ахтямов М. К. Интеллектуализация предпринимательства как объективная закономерность развития экономики знаний / М. К. Ахтямов, Н. А. Кузнецова, Л. В. Саакова // Российское предпринимательство. 2011. - № 4 (2). - С. 16-20.

3. Мельник О. Л. Інформаційне суспільство та суспільство знань - становлення та розвиток понять / О. Л. Мельник // Вісник національного технічного університету України «Київський політехнічний інститут». Філософія. Психологія. Педагогіка. - 2007. - № 2. - Ч. 2. - [Електроний pecypc]. - Режим доступу: http://novyn.kpi.ua/2007-2-2/12_Melnik.pdf (дата 12.09.2018). - Назва з екрану.

4. Bradicich, T. The Intelligent Edge: What it is, what it's not, and why it's useful. 2017. Retrieved from https://www.hpe.com/us/en/insights/articles/ the-intelligent-edge-what-it-is-what-its-not-and-why-its-useful-1704.html

5. Hewlett Packard Enterprise. Интеллектуальные технологии. - [Электронный ресурс]. - Режим доступа: https://www.hpe.com/ru/ru/what-is/ intelligent-edge.html\# (дата 20.09.2018). - Название с экрана. 